\title{
Electrochemistry in Thin Solid Films of Prussian Blue: A Model Demonstration of Reversible Behavior
}

\author{
Ryan Hazen, Rose M. Spaulding, and Kasem K. Kasem* \\ Natural, Information, and Mathematical Sciences \\ Indiana University Kokomo \\ Kokomo, Indiana 46904 USA \\ Ellen A. Sigle \\ Division of Education \\ Indiana University Kokomo \\ Kokomo, Indiana 46904 USA
}

Received May 8, 2002

Accepted January 10, 2003

\begin{abstract}
This article discusses the effectiveness of Prussian Blue (PB) or $\mathrm{K}_{x} \mathrm{Fe}_{A}{ }^{\mathrm{X}}\left[\mathrm{Fe}_{B}{ }^{\mathrm{Y}}(\mathrm{CN})_{6}\right]_{z}$ thin films as a model to demonstrate the concept of reversibility of electron and ion exchange processes. $\mathrm{PB}$ structure is modified via exchanging the $\mathrm{Fe}_{\mathrm{A}}$ (the counter ion) with other metal ions that have electrochemically active or inactive redox behavior. The modeling process includes the investigation of the electrochemical behavior of PB before and after modification. The results can be compared and used to derive conclusions about the validity of PB as a model compound.
\end{abstract}

\section{INTRODUCTION}

Reversible behavior is one of the most important characteristics in the chemical process. Investigating the concept of reversibility has become paramount in light of the ever-increasing demand for recycling. Fuel cells and rechargeable batteries are clear examples of the usefulness of the reversibility process. Regeneration of a particular byproduct of energy-producing reactions requires a full understanding of their reversibility.

Understanding the behavior of matter requires advanced reasoning skills. These can be developed by performing experimental work to generate information that can be used for direct explanation of observed phenomena, or by designing further experimental work to enhance understanding. In the field of chemistry, it is necessary to develop research experiences using materials that clearly demonstrate the concepts to be learned.

An important aspect of the constructivist approach is to design a lesson that lends itself to independent learning [1]. The use of the modeling approach is an indispensable step in this endeavor. The work done in this paper is designed to address the use of Prussian Blue to demonstrate the concept of charge and ion exchange reversibility.

Iron hexacyano-Iron (III) traditionally known as Prussian Blue (PB) has several characteristics that support its use by educators as a material in demonstrations. These characteristics are that PB compounds are: easy to prepare, safe to handle, very stable, and electrochemically

*Author for correspondence 
active as its CV (cyclic voltammogram) has two redox centers (one for the counter iron ion $\mathrm{Fe}_{\mathrm{A}}(\mathrm{III} / \mathrm{II})$, and the other for the central iron ion in $\mathrm{Fe}(\mathrm{CN})_{6}{ }^{3-14-}[2,3,4]$.

In light of these positive attributes, a detailed procedure describing how PB can be used to observe and demonstrate electrochemical behavior will be presented, and a series of research questions will be suggested that can be used to further clarify its instructional components. This researchteaching article suggests a means of handling the important question that first comes across the student's mind, and shows how that answer can lead to further investigations of electrochemical behavior.

The experimental work described in this article represents a follow-up for students who have had some hands on work with cyclic voltammetry. Students must first understand and master the concepts of cyclic voltammetry. We recommend that students review articles that discuss the basics of $\mathrm{CV}$ experiments, such as Kissinger and Heineman [5] and other related articles [6-17].

Students involved in this study were senior chemistry majors who participated in an undergraduate research program. Actual questions that have been asked by these students will be included to add emphasis to the points covered. We shall refer to these students' questions as $P S Q$ (participant students' questions). In particular, experimental work will be discussed that answers the following PSQ:

1. Which $\mathrm{CV}$ redox wave is due to counter $\mathrm{Fe}$ ions $\left(\mathrm{Fe}_{\mathrm{A}}\right)$, and which one is due to central $\mathrm{Fe}$ ions in $\left[\mathrm{Fe}(\mathrm{CN})_{6}\right]^{-3}$ ?

2. How easy is it to exchange the counter Fe ions in the solid films of PB?

3. How reversible is the process of exchanging counter $\mathrm{Fe}$ ions? In other words, can we restore counter $\mathrm{Fe}$ ions to the film after they have been exchanged with other cations?

4. Would exchanging counter $\mathrm{Fe}$ ions affect the redox behavior of the central $\mathrm{Fe}$ ion?

5. Would exchanging counter $\mathrm{Fe}$ ions affect the stability of the PB film?

\section{INSTRUMENTATION AND METHODS}

a. Experimental Reagents

Compounds $\mathrm{CuCl}_{2}, \quad \mathrm{InCl}_{3}, \mathrm{FeCl}_{3}$, $\mathrm{NiCl}_{2}, \quad \mathrm{AlCl}_{3}, \quad \mathrm{RuCl}_{3}, \quad \mathrm{KCl}, \quad$ and $\mathrm{K}_{3}\left[\mathrm{Fe}(\mathrm{CN})_{6}\right] 2 \mathrm{H}_{2} \mathrm{O}$, and all other reagents were at least analytical grade and were used without further purification.

\section{b. Laboratory Equipment}

Electrochemical experiments used the electrochemical cell of the conventional three-electrode type, carried out in a small vial. The reference electrode was an $\mathrm{Ag} / \mathrm{AgCl}$ (saturated $\mathrm{KCl}$ ) half-cell whose potential was $-45 \mathrm{mV}$ vs. SCE, the counter (auxiliary) electrode was a platinum (Pt) wire, and the working electrode was glassycarbon [GCE $\left(0.071 \mathrm{~cm}^{2}\right.$ surface area, Bioanalytical Systems)]. The working electrode was cleaned by polishing with 1 $\mu \mathrm{m}$ Alumina paste and rinsed with water and acetone prior to use. A BAS 100B electrochemical analyzer (Bioanalytical Co.) was used to perform the electrochemical studies. (Any other equipment that is capable of performing $\mathrm{CV}$ also can be used.)

All electrochemical experiments were carried out following deoxygenation using nitrogen $(99.99 \%)$ gas. All experiments were performed at room temperature $\left(25.1^{\circ} \mathrm{C}\right)$. All experiments were repeated several times to confirm their reproducibility.

\section{c. Hazards}

Although the concentration levels of the compounds described in the experimental work are very low, standard laboratory safety practices should be observed at all times while performing this work. Solutions of $\mathrm{CuCl}_{2}, \mathrm{InCl}_{3}, \mathrm{NiCl}_{2}, \mathrm{AlCl}_{3}$, $\mathrm{RuCl}_{3}$ should be appropriately placed in separate marked containers and not disposed of down the drain. These ions can be precipitated as carbonates. $\mathrm{K}_{3}\left[\mathrm{Fe}(\mathrm{CN})_{6}\right] 2 \mathrm{H}_{2} \mathrm{O}$ solution can be deposited as Prussian Blue using some $\mathrm{Fe}^{3+}$. Rinsing the modified electrodes should take place in a separate container, and the rinses should not be poured down the drain. 


\section{PROCEDURE}

\section{a. Step 1, Electrode Modification}

Although the following steps can be used for any electrode material $(\mathrm{Pt}, \mathrm{Au})$, we will use a GCE for our study. Modification of the GCE with the desired redox active insoluble film of $\mathrm{K}_{\mathrm{x}} \mathrm{Fe}\left[\mathrm{Fe}(\mathrm{CN})_{6}\right]_{z}$ or $\mathrm{PB}$, took place using the electrochemical method. This method requires:

1. Freshly prepared $1 \mathrm{mM}$ aqueous solutions of $\mathrm{FeCl}_{3}$ and of $\mathrm{K}_{3} \mathrm{Fe}(\mathrm{CN})_{6}$.

2. Supporting electrolyte of $40 \mathrm{mM} \mathrm{KCl}$ $(\mathrm{pH}$ of 2). The $\mathrm{pH}$ was adjusted using $\mathrm{HCl}$.

3. Repetitive potential cycling between 1.0 and -0.20 Volts versus $\mathrm{Ag} / \mathrm{AgCl}$ of GCE in the solution made in the previous two steps. Unless stated otherwise, the potential scan rate was $0.100 \mathrm{Volts} / \mathrm{second}$.

The formation of the film and its growth were detected by monitoring the increase in the reduction or oxidation peak of the resultant voltammograms. The effects of other parameters, such as different scan rates and the number of cycles on the amount of deposited film, were also investigated.

\section{b. Step 2, Characterization of the Modified Electrode}

i) Redox systems: The modified electrodes, prepared as described in the previous step, were thoroughly rinsed with de-ionized water and transferred to another cell that contains only the supporting electrolyte. These electrodes were subjected to repetitive potential cycling between 1.0 and -.20 Volts vs. $\mathrm{Ag} / \mathrm{AgCl}$ at 0.100 Volts/second until constant CVs were produced. These CVs are used to identify the redox system/s in the film. To correlate each redox system to its appropriate redox center in the film, $\operatorname{In}^{3+}$ (as a nonelectroactive ion) was used to replace the counter ion $\mathrm{Fe}_{\mathrm{A}}$ in the $\mathrm{PB}$ film, so the observed redox wave in the obtained $\mathrm{CV}$ was due to the central $\mathrm{Fe}$ ion in PB.

ii) Quantitative Analysis: Although the work described here is qualitative, the participating students are encouraged to investigate the quantitative aspects of the PB film they produce.

- Surface Coverage $\left(\mathrm{mole} / \mathrm{cm}^{2}\right)$ : The elec-trode surface coverage $(\Gamma)$ was determined by manually integrating the area under voltammetric $\mathrm{i}-\mathrm{E}$ curves using the following formula:

$$
Q=n \cdot A \cdot F \cdot \Gamma
$$

where $Q$ is the total charge, $n$ is the number of electrons, $A$ is the electrode geometrical surface area in $\mathrm{cm}^{2}$, and $F$ stands for Faraday. The units of $\Gamma$ are mole $/ \mathrm{cm}^{2}$.

- Film Thickness (cm): Assuming a uniform distribution of the deposited film, the thickness of the PB film was determined using Film Thickness (in $\mathrm{cm}$ ) $=\Gamma \times$ Molar Volume. Calculations are based on previous research work, in which a PB cubic cell unit was found to have a length $(\ell)$ of $10.4 \AA$ and molar volume $677 \mathrm{~cm}^{3} /$ mole [16].

- Concentration (C) of the redox active centers: The concentration of $\mathrm{Fe}^{3+/ 2+}$ can be calculated, assuming a smooth and uniformly thick film, using the following formula: $\mathrm{C}\left(\mathrm{mole} / \mathrm{cm}^{3}\right)=\Gamma / \ell$.

\section{c. Step 3, lon-Exchange Properties}

The well-characterized film was used to exchange a desired cation, such as $\mathrm{In}^{3+}, \mathrm{Ru}^{3+}$, or $\mathrm{Al}^{3+}$. The ion exchange process can be achieved either by soaking the electrode for a certain time in an aqueous solution of these cations or by repetitive cycling of the potential of GCE modified with $\mathrm{PB}$ in aqueous solutions of these cations. The change in the size or the position of the redox waves in the resulting $\mathrm{CV}$ was used as an indicator of the exchange. The quantities of the exchanged cations in the PB can be determined as described in step 2.

\section{d. Step 4, Test of Reversibility}

Restoration of the counter $\mathrm{Fe}_{\mathrm{A}}$ cations in PB (that have been partially or completely exchanged) took place using the same methods mentioned in step 3 . The growth of the counter $\mathrm{Fe}_{\mathrm{A}}$ ion redox wave in the $\mathrm{CV}$ is indicative of such restoration and was used as evidence for the reversibility of the ion exchange process. 


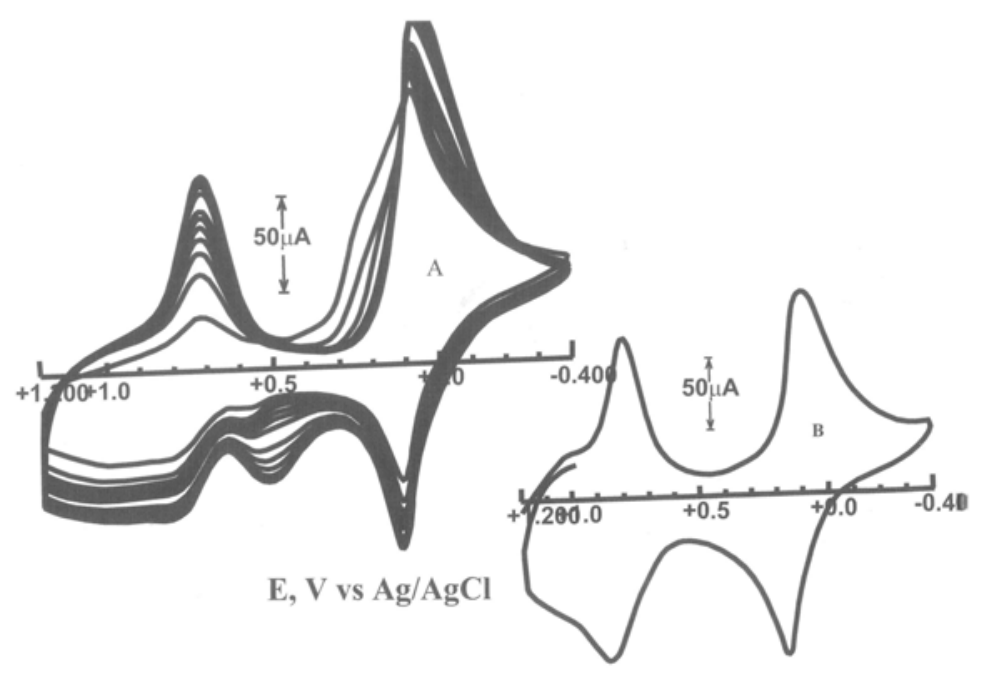

Figure 1. Electrodeposition of a PB solid film, following the procedure outlined in step 1 of section IV. The upper left figure (1A) shows a repetitive $C V$ for the formation of $K_{x-1}$ $\left\{\mathrm{Fe}^{(\mathrm{III})}\left[\mathrm{Fe}(\mathrm{CN})_{6}\right]_{\times}\right.$on GCE in $\mathrm{KCL}$ electrolyte $(\mathrm{pH}=1)$ containing $\mathrm{FeCl}_{3}$ and $\mathrm{K}_{3} \mathrm{Fe}(\mathrm{CN})_{6}$. The lower right figure (1B) shows a CV of modified GCE with $\mathrm{K}_{\mathrm{x}-1}\left\{\mathrm{Fe}^{(\mathrm{III})}\left[\mathrm{Fe}(\mathrm{CN})_{6}\right]_{\mathrm{x}}\right.$ in $\mathrm{KCL}(\mathrm{pH}=1)$. The scan rate was 0.2 Volts/second.

The following procedure was used to perform the reversibility test: 1) An electrode modified with PB was subjected to potential cycling in acidic $\mathrm{KCl}$ solution containing $10 \mathrm{mM} \mathrm{InCl}_{3}$ for 20 cycles, and the change of the peak current of the redox wave at $0.150 \mathrm{~V}$ was recorded. The electrode was then removed and rinsed with de-ionized water. 2.) A CV in the supporting electrolyte only was run to record the redox behavior of partially exchanged PB (K $\ln _{x} \mathrm{Fe}_{y}\left[\mathrm{Fe}(\mathrm{CN})_{6}\right]_{z}$. 3) The electrode was then transferred to an acidic $\mathrm{KCl}$ solution containing $\mathrm{FeCl}_{3}$ and subjected to successive potential cycling for the desired time. The electrode was then removed and rinsed with deionized water followed by potential cycling in supporting electrolyte only.

\section{RESULTS AND DISCUSSION}

\section{a. Background}

In $\mathrm{HCM}$ (hexa cyano metalates) of general formula $M_{A}{ }^{X}\left[M_{B}{ }^{Y}(C N)_{6}\right]_{Z}, M_{B}{ }^{Y}$ is the central atom, while $\mathrm{M}_{A}{ }^{X}$ is the fixed counter cation. Both $M_{A}{ }^{X}$ and $M_{B}{ }^{Y}$ are generally transition metals. The reduction of the fixed counter cation in these compounds can take place via electron/cation addition according to the following reaction:

$$
\begin{aligned}
& M_{A}^{x}\left[M_{B}^{Y}(C N)_{6}\right]_{z}+1 e+K^{+} \\
& \quad \Rightarrow K M_{A}^{x-1}\left[M_{B}^{y}(C N)_{6}\right]_{Z}
\end{aligned}
$$

The oxidation of the central atom can also take place by electron loss followed by anion addition as follows:

$$
\begin{aligned}
& M_{A}^{x}\left[M_{B}^{\gamma}(C N)_{6}\right]_{z}-1 e+X^{-} \\
& \Rightarrow M_{A}^{x}\left[M_{B}^{Y+1}(C N)_{6}\right]_{Z}
\end{aligned}
$$

The color of the reduced or the oxidized form depends on $M_{A}{ }^{X}$ and $M_{B}{ }^{Y}$ in $P B$.

\section{b. Electrodeposition of PB Solid Film}

Following the procedure described in step 1, the resultant CVs are displayed in Figures $1 \mathrm{~A}$ and $\mathrm{B}$.

PSQ: How do we know that there is a film building up on the electrode surface? 
The growth of the redox waves at either 0.10 $\mathrm{V}$ or $0.750 \mathrm{~V}$ versus $\mathrm{Ag} / \mathrm{AgCl}$ (note the scan numbers) in Figure $1 \mathrm{~A}$, indicates that an active redox center is immobilized at the electrode surface and that it keeps building up a stable film. Furthermore, Figure $1 \mathrm{~B}$ is a display of the CV obtained for the GCE modified with PB film in the supporting electrolyte only (see step 2). The following points can be deduced from the comparison of Figures $1 \mathrm{~A}$ and 1B:

1) The immobilized film shows two redox waves at $0.1 \mathrm{~V}$ and $0.80 \mathrm{~V}$ which is $100 \mathrm{mV}$ more positive than those observed in Figure $1 \mathrm{~A}$.

2) The oxidation wave shown at 0.5 $\mathrm{V}$ in Figure $1 \mathrm{~A}$ is absent in Figure $1 \mathrm{~B}$.
3) Both redox waves are surface type. However, $\Delta E_{p}$ is not zero because of some uncompensated IR drop.

\section{c. Identification of the Redox Centers Waves}

PSQ: Which of the two redox waves shown in Figure $1 B$ is due to the counter Fe ions in $P B$ ?

The GCE modified with PB was subjected to potential cycling in acidic $\mathrm{KCl}$ solution containing $10 \mathrm{mM} \mathrm{InCl}_{3}$. The results, displayed in Figure $2 \mathrm{~A}$, demonstrate that the peak current of the redox wave at $0.15 \mathrm{~V}$ is decreasing as the number of cycles increases. This means that the following reaction took place:

$$
\begin{aligned}
& K_{X} \mathrm{Fe}\left[\mathrm{Fe}(\mathrm{CN})_{6}\right]_{Y}+\mathrm{In}^{3+} \\
& \quad \Rightarrow K_{X} \operatorname{In}\left[\mathrm{Fe}(\mathrm{CN})_{6}\right]_{Y}+\mathrm{Fe}^{3+}
\end{aligned}
$$

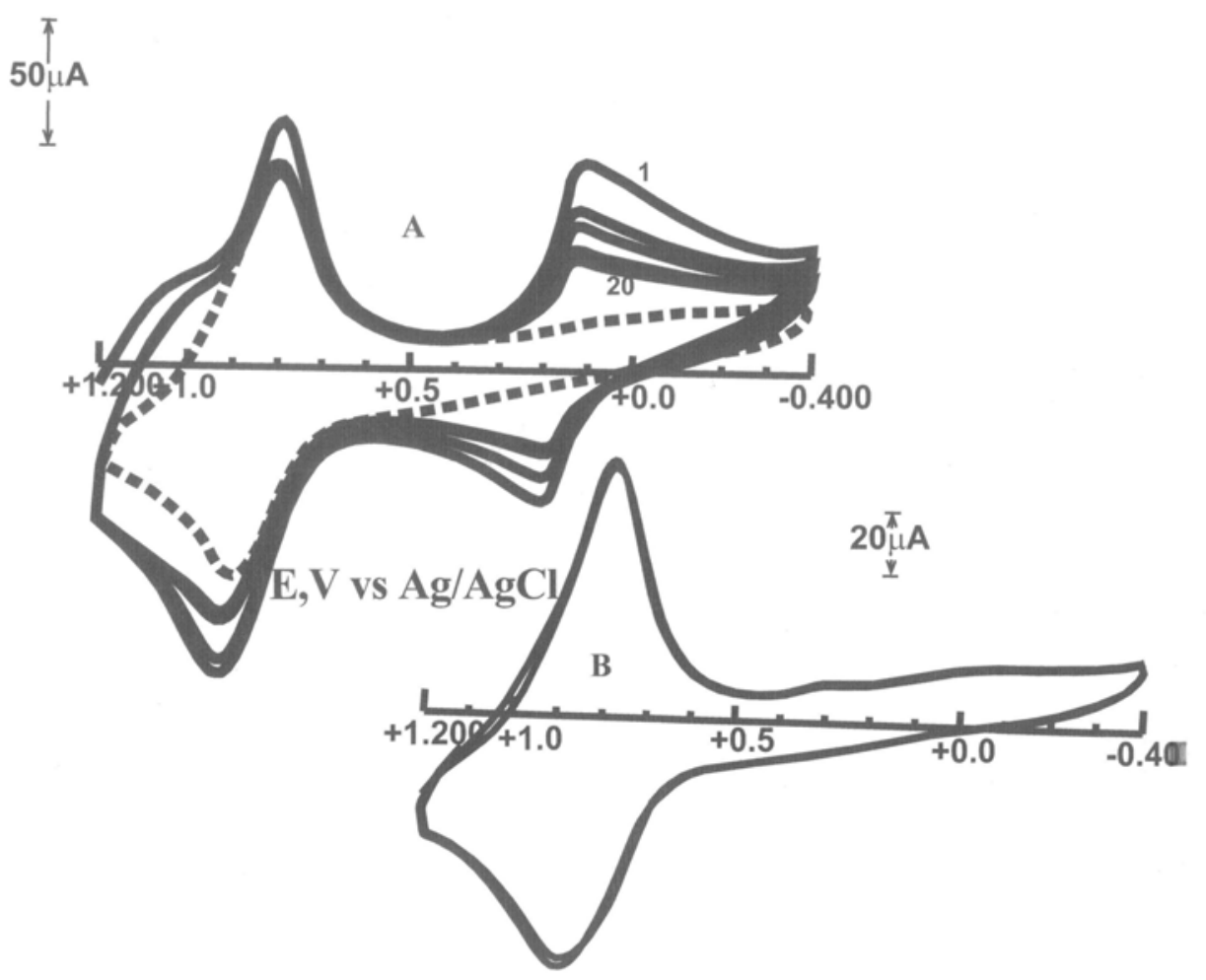

Figure 2. The upper left figure (2A) shows repetitive CV's of a GCE modified with $\mathrm{K}_{\mathrm{X}-1}$ $\left\{\mathrm{Fe}^{(\mathrm{IIII})}\left[\mathrm{Fe}(\mathrm{CN})_{6}\right] \mathrm{x}\right.$ in acidic $10 \mathrm{mM} \mathrm{InCl} / \mathrm{KCl}$, with a scan rate of $0.2 \mathrm{~V} / \mathrm{s}$. The scan numbers are written on the curves, and the dashed curve is for $\mathrm{CV}$ after 20 hours. The lower right figure (2B) shows a $\mathrm{CV}$ of $\mathrm{K}_{\mathrm{X}} \mathrm{In}_{\mathrm{Y}}\left[\mathrm{Fe}(\mathrm{CN})_{6}\right](\mathrm{s})$ in $\mathrm{KCl}(\mathrm{pH}=1)$, with a scan rate of $0.2 \mathrm{~V} / \mathrm{s}$. 


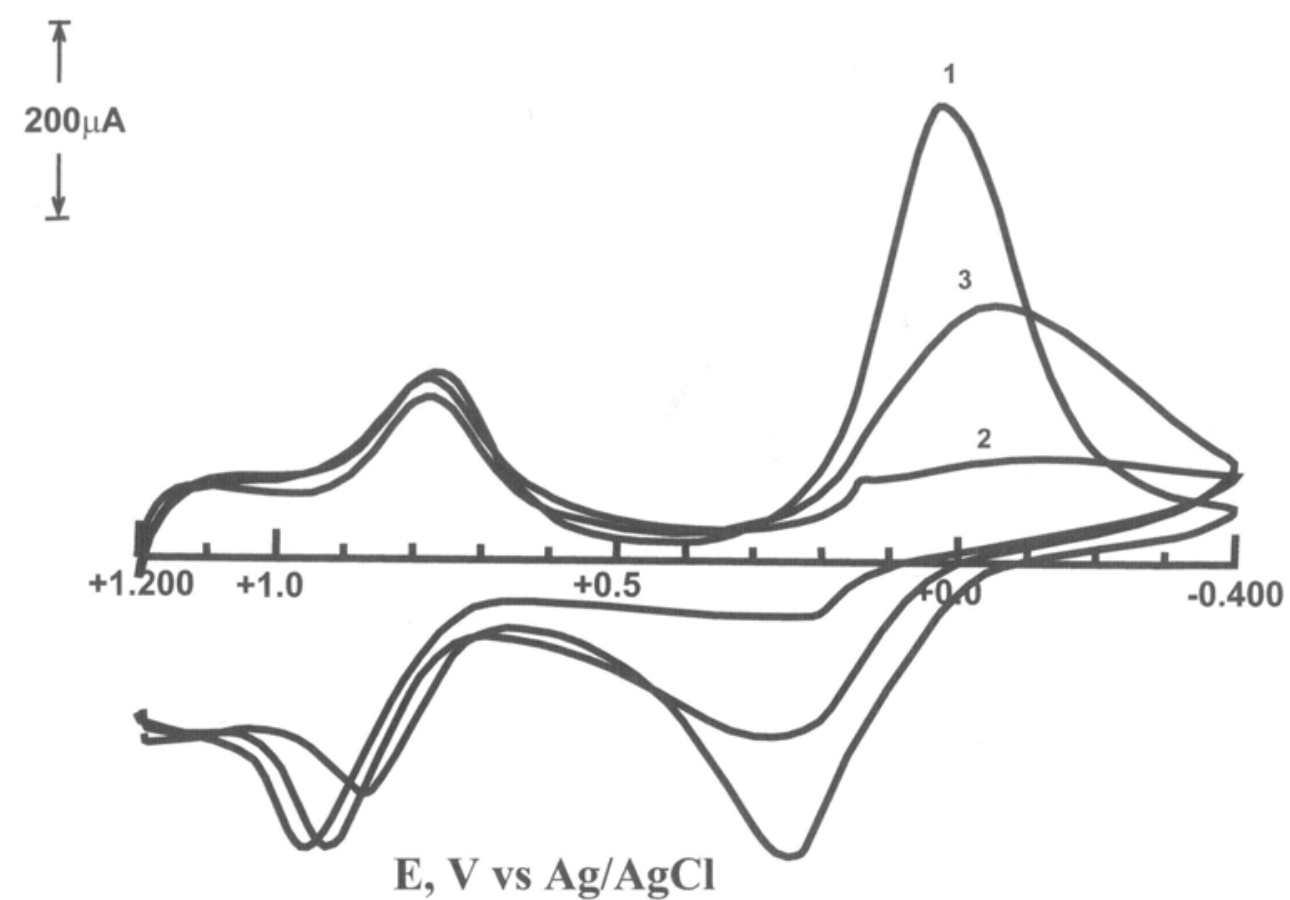

Figure 3. CV's of a CGE modified with $\mathrm{K}_{\mathrm{x}-1} \mathrm{Fe} \mathrm{e}^{(\mathrm{III})}\left[\mathrm{Fe}(\mathrm{CN})_{6}\right]_{\mathrm{x}}$ in $\mathrm{KCL}$ electrolyte $(\mathrm{pH}=1)$, with a scan rate of $0.2 \mathrm{~V} / \mathrm{s}$. Curve 1 shows the CV with the GCE freshly prepared; curve 2 is after undergoing 20 potential cycles in $10 \mathrm{mM}$ of acidic $\mathrm{InCl}_{3}$ solution; curve 3 shows a CV after the further cycling in acidic $\mathrm{FeCl}_{3}$, as described in [2].

The decrease of the peak current at $0.15 \mathrm{~V}$ can be attributed to loss of the counter $\mathrm{Fe}_{\mathrm{A}}$ ion in PB. This is because $\ln ^{3+}$ is electrochemically inactive. Therefore, the redox wave at $0.85 \mathrm{~V}$ must be due to the central $\mathrm{Fe}$ in $\mathrm{Fe}(\mathrm{CN})_{6}{ }^{3+}$. This conclusion is confirmed after performing $\mathrm{CV}$ on $\mathrm{K}_{\mathrm{x}}$ $\operatorname{In}\left[\mathrm{Fe}(\mathrm{CN})_{6}\right]_{y}$ film prepared from $\mathrm{InCl}_{3} / \mathrm{K}_{3} \mathrm{Fe}(\mathrm{CN})_{6}$ as described in step 1 (see Figure 2B, which shows no redox wave at $0.15 \mathrm{~V}$ ). Since we have been able to identify the redox waves in the $\mathrm{CV}$ of $\mathrm{PB}$, we consider that reaction 1 takes place at the reduction peak at $0.15 \mathrm{~V}$, while reaction 2 takes place during the oxidation peak at $0.85 \mathrm{~V}$.

d. Rate of Exchanging the Counter lon

Figure 3 indicates that majority of $\mathrm{Fe}^{3+}$ has been replaced with $\operatorname{In}^{3+}$ in the first
20 cycles. The removal of most of the $\mathrm{Fe}^{3+}$ was achieved after 20 hours (curve 2). Figure 3 also indicates that the exchange of $\mathrm{Fe}$ counter ions was accompanied by decrease in the peak currents of the central $\mathrm{Fe}$ ion in the film. On the other hand, the formal redox potential of the central $\mathrm{Fe}$ remains constant at $0.800 \mathrm{~V}$.

\section{e. Reversibility of Ion Exchange Process}

PSQ: Can the counter Fe ions in $P B$ that have been replaced by In ions be rehabilitated in the film?

The procedure for the reversibility test has been performed as described in step 4. The results are displayed in Figures 3 , and 4 . Figure 3 indicates that: 


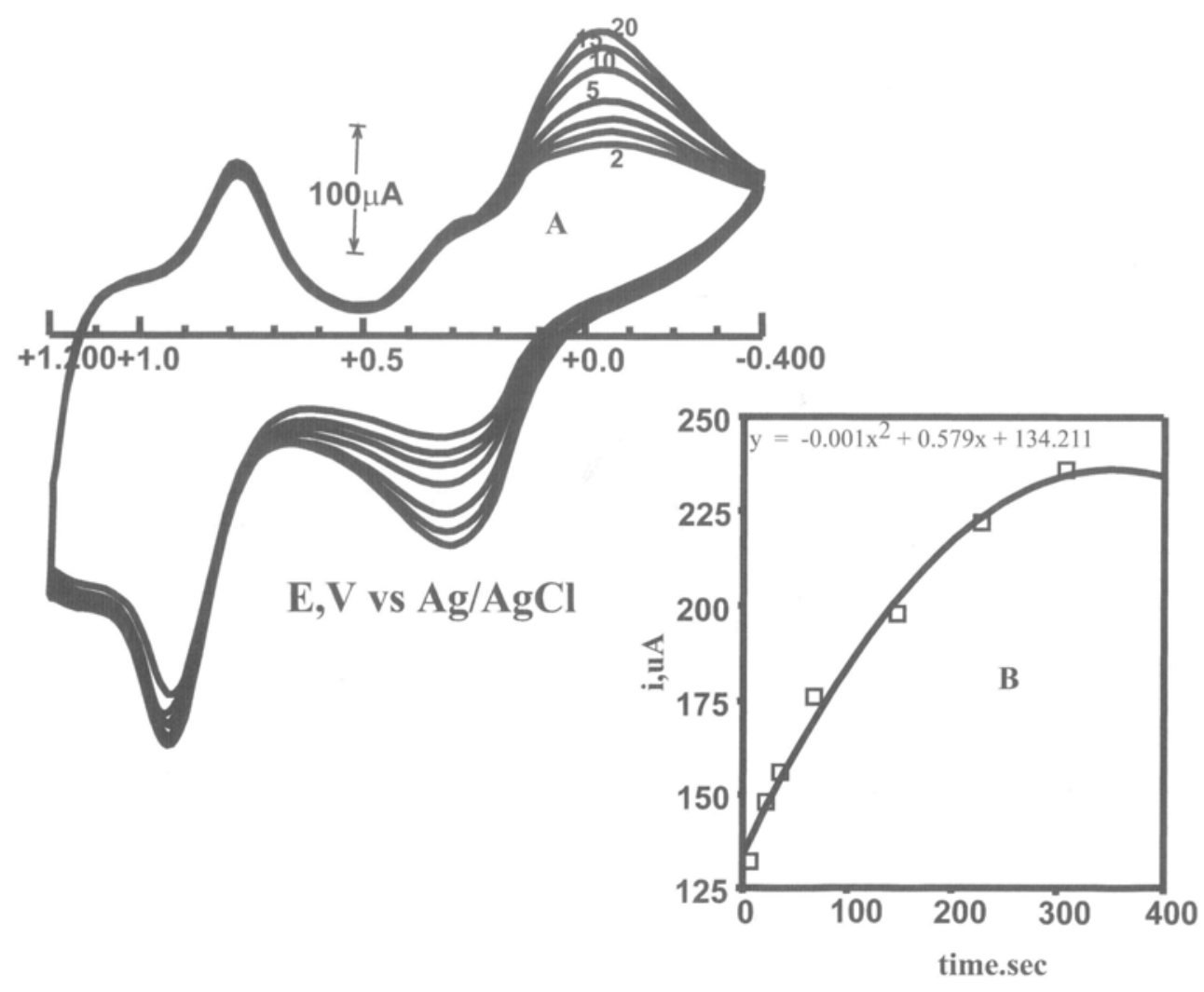

Figure 4. The upper left figure (4A) shows repetitive CV's of a GCE modified with $\mathrm{K}_{\mathrm{X}} \operatorname{In}_{\mathrm{Y}}\left[\mathrm{Fe}(\mathrm{CN})_{6}\right](\mathrm{s})$ in $\mathrm{FeCl}_{3} / \mathrm{KCl}(\mathrm{pH}=1)$, with a scan rate of $0.2 \mathrm{~V} / \mathrm{s}$. The redox wave at $\approx 0.0 \mathrm{~V}$ is a combination of free and immobilized Fe ions in the film. The lower right inset figure (4B) is a plot of the rate of iron/indium exchange (in $\mu \mathrm{A}$ ) versus time. The non-linear relationship indicates that the greatest rate of exchange took place at the beginning, as more than $54 \%$ of the iron entered into the film matrix, in the first 20 cycles.

1) In the presence $\operatorname{InCl}_{3}$, (curve 2) the peak current of the redox wave at 0.150 $\mathrm{V}$ has dropped considerably. Furthermore, the cathodic potential and the current of central $\mathrm{Fe}$ redox wave (at $0.800 \mathrm{~V}$ ) remain constant. The anodic current and potential of this wave was slightly greater than that of the original film (curve 1).

2) In the presence of $\mathrm{FeCl}_{3}$ solution (curve 3) the peak current of the redox wave at $0.150 \mathrm{~V}$ increases after 20 cycles. While the cathodic current of central Fe redox wave (at $0.800 \mathrm{~V}$ ) was less than that of the original film, the anodic current and the potential of central $\mathrm{Fe}$ redox wave (at 0.800 V) was slightly changed. This indicates that while the restoration of $\mathrm{Fe}$ ions back to the $\mathrm{PB}$ is possible, the film assembly is not identical to the original one.
On the other hand Figure 4A, displays CV's of Indium hexacyano iron (III) film in acidic $\mathrm{FeCl}_{3}$ solution, while Figure $4 \mathrm{~B}$ is the plot of the rate of iron/indium exchange versus time. The non-linear relationship shown in this figure indicates that the greatest rate of exchange took place at the beginning as more than $54 \%$ of iron entered to the film matrix in the first 20 cycles compared with the amount that entered after 75 minutes. The results displayed in Figures 3 and 4 also indicate that the process of replacing the counter $\mathrm{Fe}$ ions in PB is reversible.

PSQ: Are the redox potential of the counter ion and that of central ion related? 


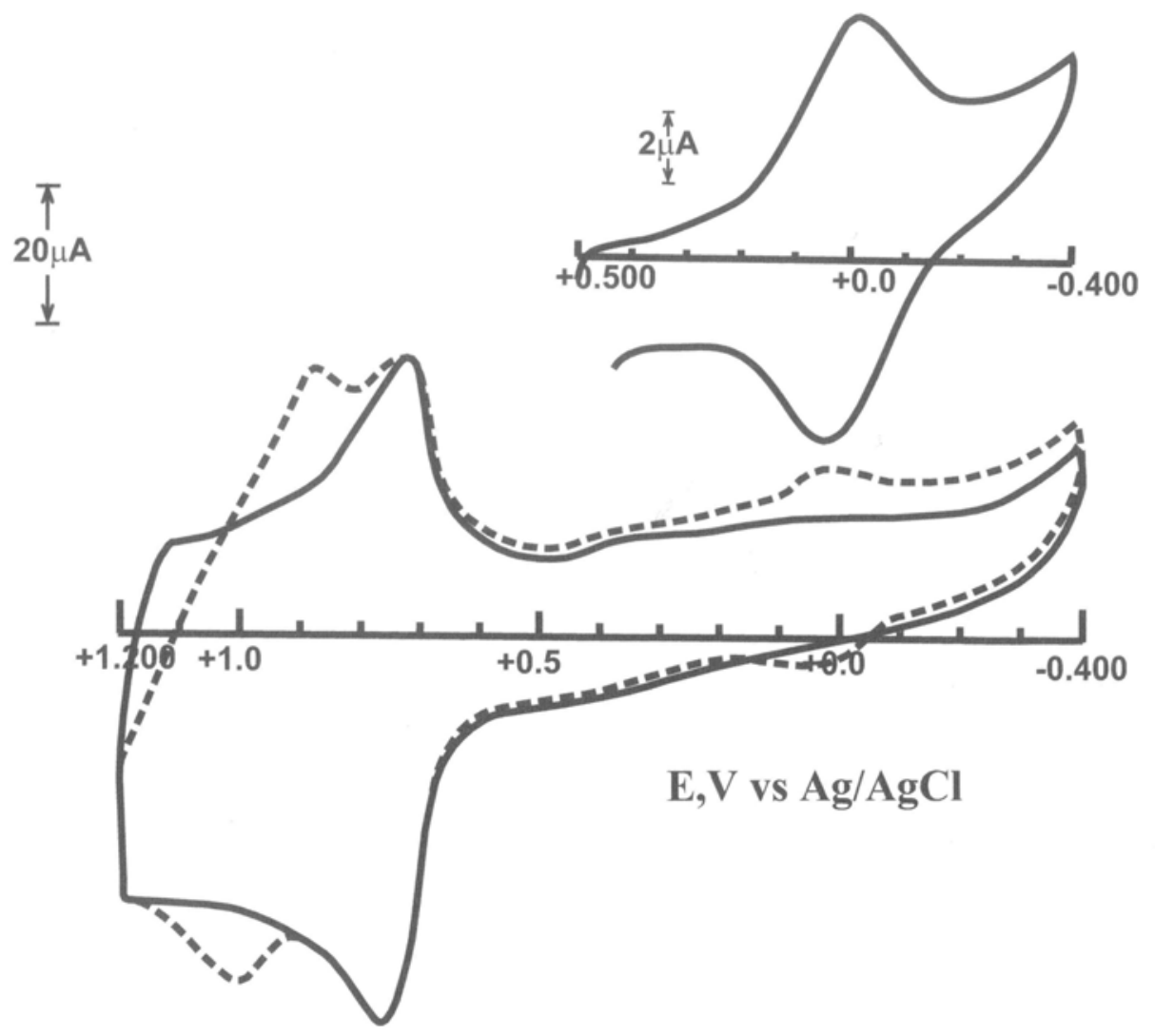

Figure 5. CV's of a GCE modified with $\mathrm{K}_{X} \ln _{Y}\left[\mathrm{Fe}(\mathrm{CN})_{6}\right]$ in $\mathrm{KCl}(\mathrm{pH}=1)$ [solid curve] and after being immersed in $10 \mathrm{mM}$ of acidic $\mathrm{RuCl}_{3}$ [dashed curve], with a scan rate of $0.2 \mathrm{~V} / \mathrm{s}$. The upper inset shows a close up view for the redox wave near $0.0 \mathrm{~V}$. The recorded CV's are scans 1-20.

This can be clarified through the following studies.

\section{f. Counter Cation Effect}

i) On the Central $\mathrm{Fe}$ atom in $\mathrm{Fe}(\mathrm{CN})_{6}^{-3 /-4}$ Redox potential: As noted earlier, the redox potential of central $\mathrm{Fe}$ atom in PB is more positive than that of the counter $\mathrm{Fe}$ ion (see Figure 2). In order to insure that this will always be the case, a modified GCE with $\mathrm{K}_{\mathrm{X}} \ln _{Y}\left[\mathrm{Fe}(\mathrm{CN})_{6}\right]$ was subject to the ion exchange process (as described in step 3 ), using $\mathrm{Ru}^{3+}$ to exchange $\mathrm{In}^{3+}$ as a counter ion. The results are displayed in Figure 5, illustrating a redox wave at̃ $0.960 \mathrm{~V}$ followed by another redox wave at $0.730 \mathrm{~V}$ (dashed curve). The fact that the redox wave at $0.960 \mathrm{~V}$ decreased when the Ru ions were exchanged by In ions indicates that this redox wave is due to the redox system $\mathrm{Ru}^{3+} / \mathrm{Ru}^{2+}$. Since $\mathrm{Ru}$ ions are counter ions in this assembly, we see that the redox potential of the central $\mathrm{Fe}$ can be less positive than that of the counter ion. Figures 2 and 5 indicate that replacing $\mathrm{Ru}^{3+}$ as a counter ion in $\mathrm{K}_{\mathrm{x}} \mathrm{Ru}_{\mathrm{y}}\left[\mathrm{Fe}(\mathrm{CN})_{6}\right]$ does not change the redox wave at $0.80 \mathrm{~V}$. The inset in Figure 5 shows a redox wave around $0.00 \mathrm{~V}$, this wave is related to a $\mathrm{K}_{\mathrm{x}} \mathrm{Ru}_{\mathrm{y}}\left[\mathrm{Fe}(\mathrm{CN})_{6}\right]$ film that coexists with the $\mathrm{K}_{\mathrm{x}} \mathrm{In} \mathrm{n}_{\mathrm{y}}\left[\mathrm{Fe}(\mathrm{CN})_{6}\right]$ film. This can be confirmed by viewing the $C V$ of a modified GCE with $\mathrm{K}_{\mathrm{x}} \mathrm{Ru} \mathrm{u}_{\mathrm{y}}\left[\mathrm{Fe}(\mathrm{CN})_{6}\right]$ (prepared as described in step 1) as displayed in Figure 6. The redox potential of $\mathrm{Ru}^{3+} / \mathrm{Ru}^{2+}$ is shown at $1.05 \mathrm{~V}$, while the redox wave shown at $0.85 \mathrm{~V}$ is due to $\mathrm{Ru}$ oxides [18], while the well defined redox wave at $0.00 \mathrm{~V}$ is due to the central $\mathrm{Fe}$ atom in $\mathrm{Fe}(\mathrm{CN})_{6}{ }^{-3 / 4}$. Furthermore, studies 


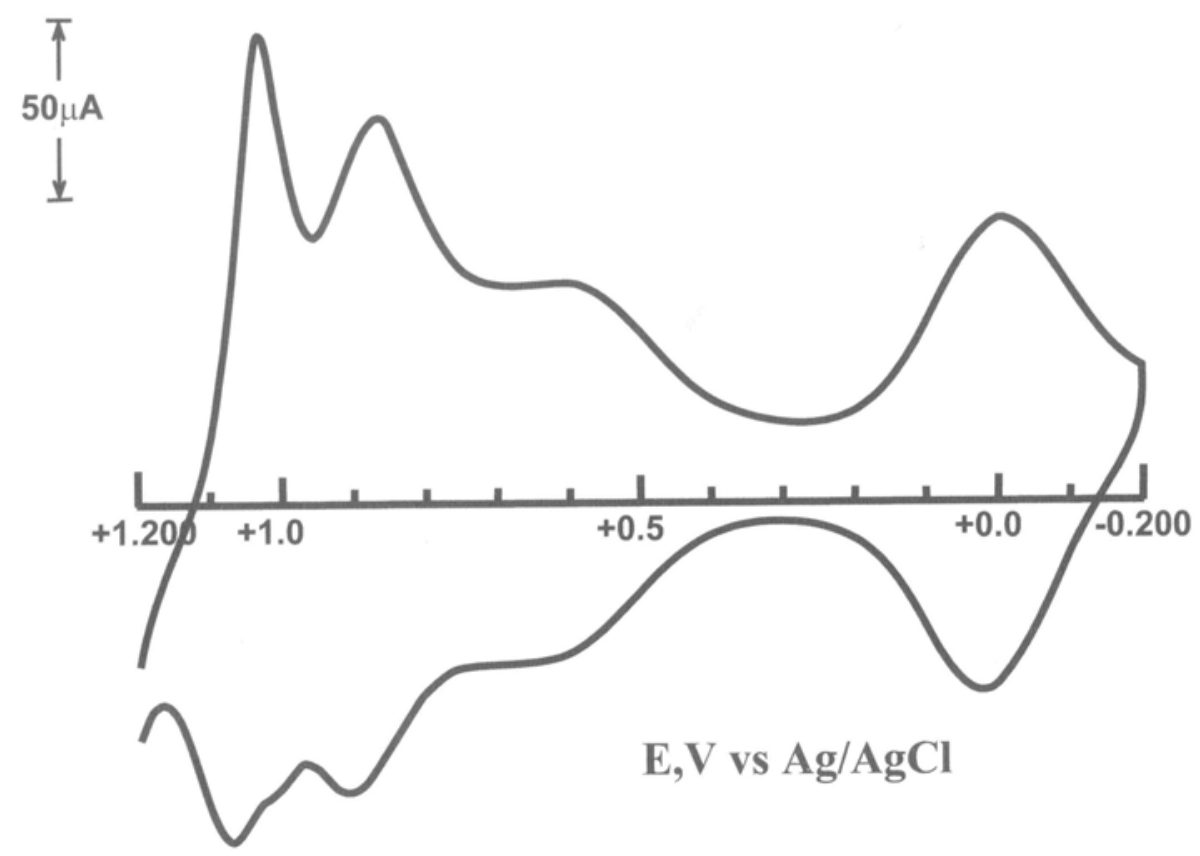

Figure 6. CV of a GCE modified with $\mathrm{K}_{x} \mathrm{Ru}_{Y}\left[\mathrm{Fe}(\mathrm{CN})_{6}\right]$ in $\mathrm{KCl}(\mathrm{pH}=1)$, with a scan rate of $0.2 \mathrm{~V} / \mathrm{s}$.

have shown that $\mathrm{Fe}^{3+}$ incorporation in the same modified electrode came at the expense of $\mathrm{Ru}$ oxides as the redox wave corresponding to these oxides $\tilde{(0.85} \mathrm{V})$ almost disappeared (results not shown).

ii) On the stability of PB:

PSQ: Would the substituted PB be more stable than the un-substituted one?

When a modified electrode with $\mathrm{K}_{\mathrm{x}} \ln _{\mathrm{y}}\left[\mathrm{Fe}(\mathrm{CN})_{6}\right]$ film is subjected to ion exchange with $\mathrm{Ru}^{3+}$ (as described in step 3), the redox wave at $0.75 \mathrm{~V}$ maintains a constant peak current $\left(i_{p c}\right.$ and $\left.i_{p a}\right)$, where $i_{p c}$, and $i_{p a}$ are the cathodic and anodic peak currents, respectively. These observations mean that replacing In ions by $\mathrm{Ru}$ ions did not cause loss (deterioration) in the film composition. This replacement process is described by the following equation:

$$
\begin{aligned}
& R u^{3+}+K_{x} I n_{y}\left[\mathrm{Fe}(\mathrm{CN})_{6}\right](s) \\
& \leftrightharpoons K_{x} R u_{y}\left[\mathrm{Fe}(\mathrm{CN})_{6}\right](s)+I n^{3+}
\end{aligned}
$$

This indicates that Ru stabilized the film since the film's resistance to deterioration or dissolution measures its stability. On the other hand, Figure 3 shows that when PB undergoes a similar ion exchange process in an $\mathrm{InCl}_{3}$ solution, then there is a decrease in $\mathrm{i}_{\mathrm{pc}}$ and $\mathrm{i}_{\mathrm{pa}}$ of the redox wave at $0.750 \mathrm{~V}$-the redox wave of the central $\mathrm{Fe}$ atom in $\mathrm{K}_{\mathrm{x}} \ln _{\mathrm{y}}\left[\mathrm{Fe}(\mathrm{CN})_{6}\right](\mathrm{s})$. Similar behavior was noticed also with $\mathrm{PB}$ in $\mathrm{AlCl}_{3}, \mathrm{CuCl}_{2}, \mathrm{NiCl}_{2}$, and $\mathrm{CdCl}_{2}$. This means that exchanging the counter ions in PB by these cations makes it less stable.

\section{CONCLUSION}

Using cyclic voltammetry, we have used PB as a model to demonstrate the concept of reversibility. This concept was illustrated by way of:

1) The easy of exchange the counter $\mathrm{Fe}$ ions in $\mathrm{K} \ldots \mathrm{Fe}\left[\mathrm{Fe}(\mathrm{CN})_{6}\right]$;

2) The reduction and oxidation of central $\mathrm{Fe}$ ions in $\mathrm{K} \ldots \mathrm{Fe}\left[\mathrm{Fe}(\mathrm{CN})_{6}\right]$; and

3) The independent reversible behavior of each redox center. 
Finally, we note that the reversibility action has some effect on the overall stability of PB films on the electrode surface.
This reversible reaction can be simplified by the following reactions:

$$
\begin{gathered}
K \ldots M_{A}^{x}\left[F e^{(I I I)}(C N)_{6}\right]_{z}+M_{z}^{y} \Rightarrow K \ldots M_{z}^{y}\left[F e^{(I I I)}(C N)_{6}\right]_{z}+M_{A}^{x} \text { for the counter ion, and } \\
K \ldots M_{A}^{x}\left[F e^{(I I)}(C N)_{6}\right]_{z}-e+X^{-} \Rightarrow K \ldots M_{A}^{x}\left[F e^{(I I I)}(C N)_{6}\right]_{z} \text { for the central ion. }
\end{gathered}
$$

Here, $\mathrm{K}$ ions were used to maintain the charge balances.

\section{REFERENCES}

1. J. Dudley Herron and Susan C. Nurrenbern, J. Chem. Educ, vol. 76, p. 1354-1362 (1999).

2. V.D. Neff, J. Electrochem. Soc., vol. 125, p. 886 (1978).

3. Kingo Itaya, H. Akahoshi, and $\mathrm{S}$. Toshima, J. Electrochem. Soc., vol. 129, p. 1498 (1982).

4. L.M. Siperko and T. Kuwana, J. Elechtochem. Soc, vol. 130, p. 396 (1983).

5. P.T. Kissinger, and W. R. Heineman, J. Chem. Educ., vol. 60, p. 702 (1983).

6. Salete L. Queiroz, Marcio P. de Araujo, J. Chem. Educ., vol. 78, pp. 89-91 (2001).

7. Henrique E. Toma and Koiti Araki, J. Chem. Educ., vol. 77, pp. 1351-1354 (2000).

8. Kathryn R. Williams, Roberto Bravo, J. Chem. Educ., vol. 77, pp. 392-395 (2000).
9. Omowunmi A. Sadik and Brenda Sharin J. Chem. Educ., vol. 76, pp. 967-971 (1999).

10. Janell E. Heffner and Jeffrey C. Raber, J. Chem. Educ., vol. 75, p. 365 (1998).

11. Jareno Garcia, J. Chem. Educ., vol. 75, p. 881 (1998).

12. Mary M. Walczak and Deborah A. Dryer, J. Chem. Educ., vol. 74, pp. 1195-1198 (1997).

13. Ali Babaei and Paul A. Connor, J. Chem. Educ., vol. 74, pp. 1200-1205 (1997).

14. Luz Maria Torres and Adrian F. Gil, J. Chem. Educ., vol. 73, pp. 808-811 (1996).

15. Stanton Ching and Ray Dudek, J. Chem. Educ., vol. 71, pp. 602-606 (1994).

16. Ralph Birdwhistell, J. Chem. Educ., vol. 69, p. 473 (1992).

17. S. Jayarama Reddy, A. Dostal, and F. Scholz, J. Electroanalyt. Chem., vol. 403, p. 209 (1996).

18. T. R. Cataldi, G. E. de Benedetto, and C. Campa, J. Electroanalyt. Chem., vol. 437, p. 93 (1997).

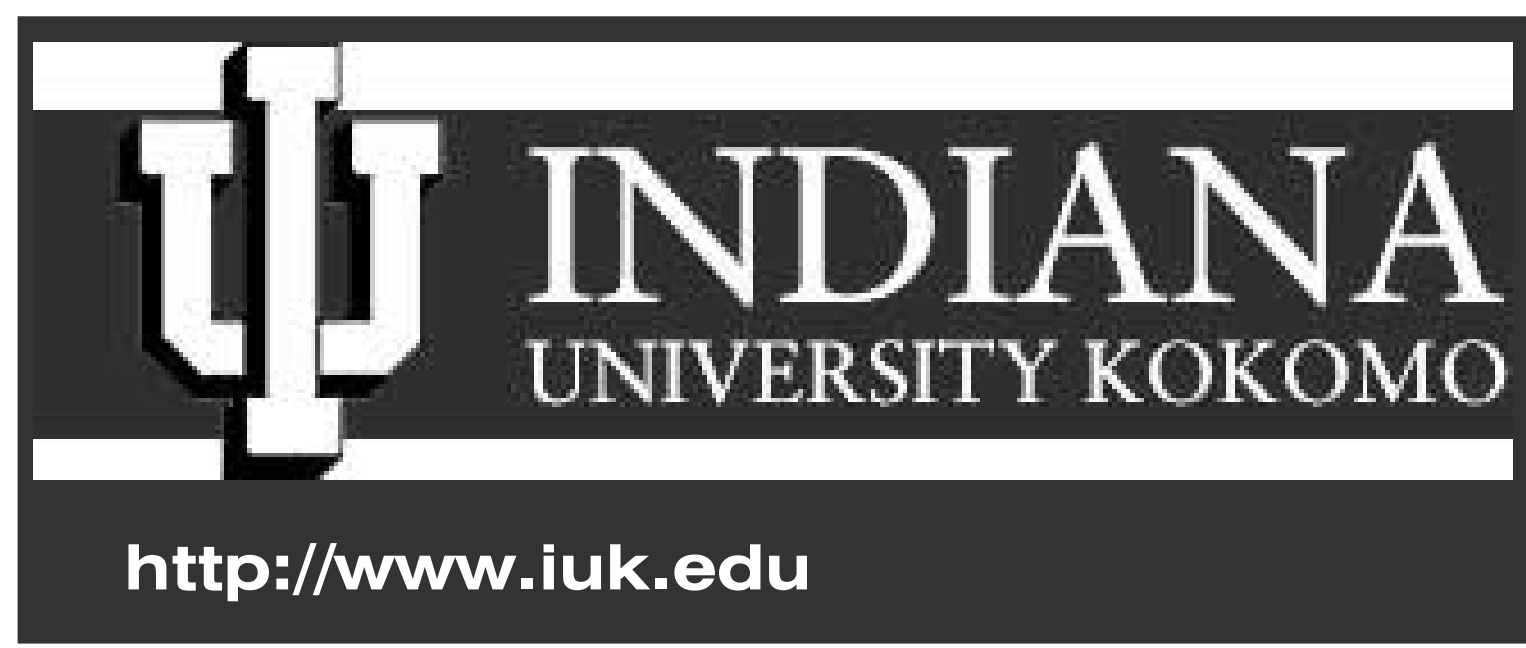

